\title{
Improving the Efficacy of Cytokinin Applications for Stimulation of Lateral Branch Development in Young Sweet Cherry Trees in the Orchard
}

\author{
Don C. Elfving ${ }^{1,3}$ and Dwayne B. Visser ${ }^{2}$ \\ Washington State University, Tree Fruit Research and Extension Center, \\ 1100 N. Western Avenue, Wenatchee, WA 98801
}

Additional index words. plant growth regulator, bioregulator, benzyladenine, gibberellic acid, auxin, Promalin, Perlan, scoring, cincturing, nicking, notching, bud removal, disbudding, bark injury, vegetative shoot growth, lateral branching, Prunus avium

\begin{abstract}
Improving lateral branch development in young sweet cherry trees without reliance on pruning is a desirable component of tree training programs, especially for high-density systems. Applications of two proprietary formulations of 6-benzyladenine and gibberellins $\mathrm{A}_{4}$ and $\mathrm{A}_{7}$ (Promalin, Valent Biosciences, Walnut Creek, Calif.; and Perlan, Fine Americas, Walnut Creek, Calif.) to individual buds or intact bark of unpruned sweet cherry central leader shoots at green-tip had little effect on lateral shoot growth from buds or on distribution of new shoot growth along the treated leader shoots. Scoring, nicking, or notching cuts alone also had inconsistent effects on shoot development and distribution. In some trials, bud removal (or disbudding, removing every fourth bud on 1-year-old shoots) produced limited improvement of lateral shoot development and vertical distribution. Combining nicking, notching, scoring, or bark scraping with the application of cytokinin-gibberellic acid solution to the cut area greatly improved both number of shoots developed and the numbers originating from the lower portions of treated leader shoots. Removing the physical barrier to bioregulator product contact with active tissues was a primary factor in improving treatment efficacy.
\end{abstract}

Sweet cherry trees exhibit strong apical dominance, producing vigorous, upright shoot growth with limited lateral branching, particularly in young trees (Elfving and Visser, 2006; Jacyna, 2002; Jacyna and Puchała, 2004; Jacyna et al., 2005; Miller, 1983). The interaction of endogenous auxins and cytokinins is thought to play a role in the control by apical dominance of lateral bud activity in the spring and during shoot development (Sachs and Thimann, 1967; Theron et al., 1987; Wickson and Thimann, 1958). Pruning can interrupt the hormonally based apical dominance control system and encourage buds that otherwise might remain quiescent to form shoots. For this reason, commonly used training systems for sweet cherries rely on pruning as a principal means for stimulation of lateral branching during canopy development (Long, 2001, 2005; Long et al., 2005; Nugent et al., 2001).

\footnotetext{
Received for publication 24 July 2006. Accepted for publication 11 Sept. 2006.

We wish to express appreciation to Bayer Environmental Science, Fine Americas, Valent BioSciences, the Washington Tree Fruit Research Commission, and the Washington State University Agricultural Research Center for products and funds partially supporting these studies.

${ }^{1}$ Horticulturist and Professor.

${ }^{2}$ Agricultural Research Technologist III.

${ }^{3}$ To whom reprint requests should be addressed; e-mail delfving@wsu.edu
}

However, pruning removes buds that might otherwise have developed into shoots or spurs and delays cropping (Elfving, 1990; Robinson et al., 2005). Therefore, alternative means for stimulation of bud growth have been examined in apple and, to a lesser extent, in sweet cherry. Scoring (a circumferential knife cut through the phloem tissue around a shoot or stem) and notching (removal of a small piece of phloem above a bud) have been used to interfere with hormone movement and to promote shoot development in apple (Cook and Strydom, 2000; Greene and Autio, 1994; Greene and Miller, 1988; Niu et al., 1998; Ouellette et al., 1996). Bud removal (disbudding) can affect and may improve shoot growth in apple and other tree fruit species (Mika et al., 1983; Peano et al., 2005), and may show promise for shoot growth stimulation in sweet cherry as well (Perry, 1999; Robinson et al., 2005). Very limited information suggests scoring or notching in the spring may positively affect lateral shoot development in sweet cherry (Long, 2005; Long et al., 2005).

Proprietary mixtures containing the cytokinin 6-benzyladenine (BA) and gibberellic acid isomers $\mathrm{GA}_{4+7}$ [Promalin (PR) or Perlan (PER)] can induce sylleptic shoot formation on the current season's shoots when applied during active shoot growth in both apple and cherry (Cody et al., 1985a,b; Elfving and Visser, 2005, 2006; Hrotkó et al., 1999; Jacyna, 2002; Neri et al., 2003; Wustenberghs and Keulemans, 1999), but few reports document the efficacy of such products for inducing shoot development from preexisting buds on 1-year-old or older wood in sweet cherry. Miller (1983) and Veinbrants and Miller (1981) reported that painting PR onto the entire surface of 1-year-old shoots of young sweet cherry trees produced some stimulation of branch development from lateral buds. Jacyna and Puchała (2004) and Jacyna et al. (1989) reported improvement in branch development and in shoot distribution when BA combined with $\mathrm{GA}_{3}$ or $\mathrm{GA}_{4+7}$ was painted on the lower two-thirds of 'Regina' sweet cherry branches or the central $30 \mathrm{~cm}$ of 'Bing' 1-year-old branches. Jacyna and Brown (1989a,b) briefly described the use of PR for one system of training young sweet cherry canopies.

Interrupting apical dominance by disrupting or altering hormonal movement to buds should lead to both increased number of lateral shoots as well as an improved spatial distribution of those shoots along the main stems or leaders on which they are borne (Jacyna and Puchała, 2004; Robinson et al., 2005). Sweet cherry growers in Washington state have reported variable results on branching from the application of cytokinin-containing products such as PR at high concentrations to individual buds at or near spring budbreak or the treatment of sweet cherry 1-year-old wood by scoring or notching above buds. The research described here was undertaken to explore in greater detail the shoot growth responses of young sweet cherry trees under Washington state conditions in terms of both shoot numbers and shoot distribution to alternative shoot-inducing treatments including scoring, nicking (a small cut with a sharp knife into the phloem without regard to location relative to a bud) or notching, or cytokinin applications for improvement of canopy development. Bud removal was also evaluated in some trials.

\section{Materials and Methods}

Seven experiments were conducted between 2003 and 2005. All trials used randomized complete block designs with five single-tree replications per treatment. Proprietary formulations of BA plus $\mathrm{GA}_{4+7}$ [Promalin (or PR), Valent BioSciences, Walnut Creek, Calif.; or Perlan (or PER), Fine Americas, Inc., Walnut Creek, Calif.] were used in the trials. Bioregulator treatments were combined with $50 \% \mathrm{v} / \mathrm{v}$ interior white latex paint and applied by hand with a small paintbrush. Bioregulator concentrations are expressed in terms of the active ingredients.

Scoring cuts were made circumferentially around the 1-year-old wood to the cambium layer with a sharp knife. Notching cuts were made by hand directly above buds with a small jigsaw blade; nicking cuts were made with a small knife without regard to bud location, making a cut into the phloem tissue to or near the cambium. Bud removal was accomplished by removing every fourth bud by hand, counting from the terminal bud and proceeding to the point of junction of 1 - and 

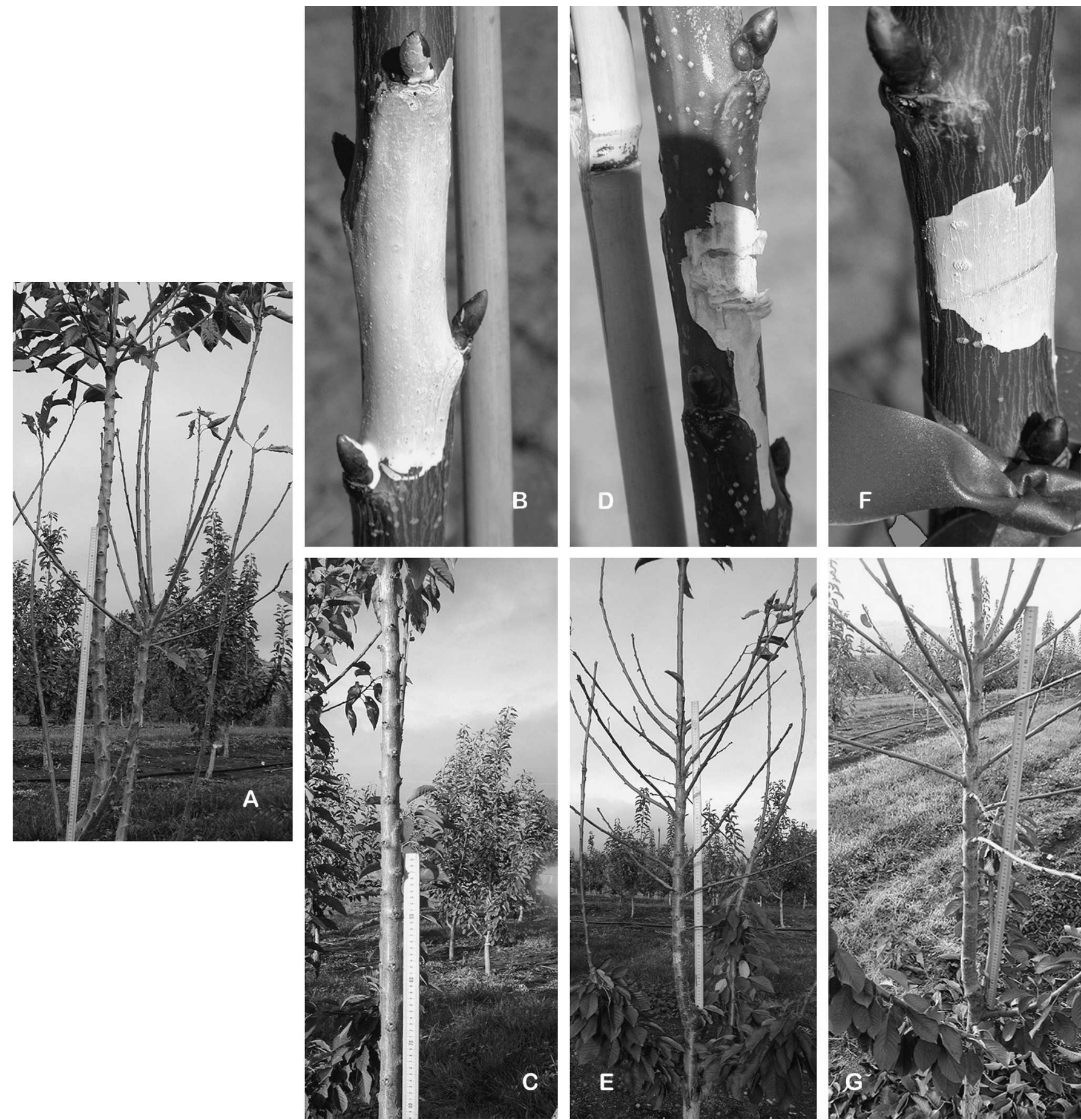

Fig. 1. Expt. 7, 2005. (A) Lateral shoot growth from unpruned leader shoot of second-leaf 'Skeena'/Mazzard sweet cherry tree. Note the strong apical dominance effect on lateral shoot location and development. (B, C) Sand epidermis plus paint PER $\left(5000 \mathrm{mg} \cdot \mathrm{L}^{-1}\right)$ on sanded area (spring, B); note absence of shoot growth response (C). (D, E) Scrape epidermis plus paint PER $5000 \mathrm{mg} \cdot \mathrm{L}^{-1}$ ) on scraped area (spring, D); note strong shoot growth and distribution response (E). (F, G) Nicking cuts plus paint PER $5000 \mathrm{mg} \cdot \mathrm{L}^{-1}$ on nicking cuts (spring, F); note strong shoot growth and distribution response $(\mathbf{G})$.

2-year-old wood. Treatments were made at green-tip each year (with green-tip defined as when a majority of the buds on 1-year-old wood was showing a point of green tissue at the distal end of the bud).

Expt. 1, 2003, Chelan Falls, Washington. Scoring cuts (a cut every $30 \mathrm{~cm}$ starting $30 \mathrm{~cm}$ below the terminal bud and repeated to the base of the 1-year-old shoot), notching cuts (cut a slot to the cambium above every fifth bud with a 0.8 -mm-thick jigsaw blade, count- ing from the terminal bud to the base of the 1year-old shoot), or bud removal were applied to a single, vertical, unpruned 1-year-old leader shoot per tree in separate second-leaf 'Bing'/Mazzard sweet cherry trees. Control trees were untreated (four treatments in total). Treatments were made at green-tip (21 Mar. 2003). After shoot growth was completed, the now second-leaf vertical leader shoot from which new lateral shoots developed was divided into $30-\mathrm{cm}$ sections in nonscored treatments or the $\approx 30$-cm sections in scoring treatments. The length of each leader shoot section was measured and all lateral shoots $(\geq 10 \mathrm{~cm}$ in length) in each section that developed in 2003 were counted and their lengths and crotch angles determined.

Expt. 2, 2003, Bray's Landing, Washington. Scoring cuts, notching cuts, or bud removal were applied as described in Expt. 1 to a single, vertical, unpruned 1-year-old 
leader shoot per tree in five replicate, secondleaf 'Rainier'/Mazzard sweet cherry trees per treatment. Treatments were made at green-tip (21 Mar. 2003). Control trees were untreated (four treatments in total). Shoot growth measurements were carried out as described for Expt. 1.

Expt. 3, 2003, Bray's Landing, Washington. The following treatments were applied at green-tip (24 Mar. 2003) to a single, vertical, unpruned 1-year-old leader shoot in each of five replicate second-leaf 'Skeena'/ Mazzard sweet cherry trees: 1) scoring cuts, notching cuts, or bud removal as described for Expt. 1; 2) PR $5000 \mathrm{mg} \cdot \mathrm{L}^{-1}$ in latex paint painted individually on every fourth bud, counting from the terminal bud in the same manner as for notching cuts as described in Expt. 1; 3) PR $5000 \mathrm{mg} \cdot \mathrm{L}^{-1}$ in latex paint applied as a ring around the leader shoot every $30 \mathrm{~cm}$ below the terminal bud to the base; or 4) scoring cuts as described earlier plus painting PR $5000 \mathrm{mg} \cdot \mathrm{L}^{-1}$ in latex paint onto the scoring cut immediately after making the cut. Control trees were untreated (seven treatments in total). Shoot growth measurements were carried out as described for Expt. 1 .

Expt. 4, 2003, Chelan Falls, Washington. The same treatments were applied in the same manner as described in Expt. 3 at green-tip (24 Mar. 2003) to each of five replicate second-leaf 'Bing'/Mazzard sweet cherry trees. Control trees were untreated (seven treatments in total). Shoot growth measurements were carried out as described for Expt. 1.

Expt. 5, 2004, Bray's Landing, Washington. All treatments were applied at green-tip (23 Mar. 2004) to three vertical, unpruned 1-year-old shoots per single-tree plot in third-leaf 'Rainier'/Mazzard sweet cherry trees. Bud removal was applied as described in Expt. 1 to one single-tree plot per block. Three single-tree plots per block were treated with notching cuts as described in Expt. 1. Three different single-tree plots per block were treated with scoring cuts, applied as two cuts, one located approximately one-third of the distance from the terminal bud to the base of the 1-year-old shoot and the second at approximately twothirds of that distance, thus dividing the treated 1-year-old shoot into thirds. In each block, one single-tree plot each of the notching cut treatments and of the scoring treatments was then painted on the cuts with PR at either $5000 \mathrm{mg} \cdot \mathrm{L}^{-1}$ in latex paint or 10,000 $\mathrm{mg} \cdot \mathrm{L}^{-1}$ in latex paint, whereas the third single-tree plot for the notching and for the scoring treatment groups received no bioregulator. Control trees were untreated (eight treatments in total). When shoot growth was completed, the length of each of the three treated sections of each of the three vertical leader shoots in each plot was measured and the total number of lateral shoots in each of the three treated sections was determined. Plot means were calculated for statistical analysis of treatment effects.

Expt. 6, 2004, Chelan Falls, Washington. Scoring cuts as described in Expt. 1 were applied at green-tip plus 1 week (31 Mar.

Table 1. Effects of bud removal, notching, or scoring on lateral shoot number, mean length, crotch angle, and vertical distribution in second-leaf 'Bing'/Mazzard sweet cherry trees (Expt. 1, 2003, Chelan Falls, Wash.).

\begin{tabular}{|c|c|c|c|c|c|c|c|c|}
\hline \multirow[b]{3}{*}{ Treatment $^{z, y}$} & \multicolumn{3}{|c|}{ Lateral shoots } & \multirow{2}{*}{\multicolumn{5}{|c|}{$\begin{array}{l}\text { Lateral shoots in leader shoot section } \\
\quad(\% \text { of total lateral shoots })^{x}\end{array}$}} \\
\hline & \multirow{2}{*}{$\begin{array}{l}\text { No./100 cm } \\
\text { limb length }\end{array}$} & \multirow{2}{*}{$\begin{array}{l}\text { Mean length } \\
(\mathrm{cm})\end{array}$} & \multirow{2}{*}{$\begin{array}{c}\text { Crotch angle } \\
\left({ }^{\circ}\right)\end{array}$} & & & & & \\
\hline & & & & 1 & 2 & 3 & 4 & 5 \\
\hline Control (untreated) & $6.4 \mathrm{a}$ & $90 \mathrm{a}$ & $65 \mathrm{~b}$ & $100 \mathrm{a}$ & $0 \mathrm{~b}$ & $0 \mathrm{~b}$ & $0 \mathrm{a}$ & $0 \mathrm{a}$ \\
\hline Bud removal & $8.2 \mathrm{a}$ & $94 \mathrm{a}$ & $69 \mathrm{ab}$ & $48 \mathrm{c}$ & $37 \mathrm{a}$ & $13 \mathrm{a}$ & $2 \mathrm{a}$ & $0 \mathrm{a}$ \\
\hline Notching cuts & $6.7 \mathrm{a}$ & $111 \mathrm{a}$ & $71 \mathrm{a}$ & $80 \mathrm{bc}$ & $13 \mathrm{~b}$ & $8 \mathrm{a}$ & $0 \mathrm{a}$ & $0 \mathrm{a}$ \\
\hline Scoring cuts & $7.8 \mathrm{a}$ & $98 \mathrm{a}$ & $65 \mathrm{~b}$ & $55 \mathrm{bc}$ & $21 \mathrm{~b}$ & $18 \mathrm{a}$ & $4 \mathrm{a}$ & $2 \mathrm{a}$ \\
\hline
\end{tabular}

zTreatments by hand to 1-year-old vertical, unpruned central leader shoots at green-tip (21 Mar. 2003).

${ }^{\mathrm{y}}$ Mean separation in columns by Waller-Duncan Bayesian k-ratio test following significant $\mathrm{F}$ test $(P \leq 0.05)$.

${ }^{\mathrm{x}}$ Mean leader shoot length was $113 \mathrm{~cm}$. Leader shoot sections $30 \mathrm{~cm}$ in length; $1=$ terminal 30 -cm section.

Sections 4 and 5 (basal) may have been less than $30 \mathrm{~cm}$.

Table 2. Effects of bud removal, notching, or scoring on lateral shoot number, mean length, crotch angle, and vertical distribution in second-leaf 'Rainier'/Mazzard sweet cherry trees (Expt. 2, 2003, Bray's Landing, Wash.).

\begin{tabular}{|c|c|c|c|c|c|c|c|c|c|}
\hline \multirow[b]{3}{*}{ Treatment $^{\mathrm{z}, \mathrm{y}}$} & \multicolumn{3}{|c|}{ Lateral shoots } & \multirow{2}{*}{\multicolumn{6}{|c|}{$\begin{array}{l}\text { Lateral shoots in leader shoot section } \\
(\% \text { of total lateral shoots })^{\mathrm{x}}\end{array}$}} \\
\hline & \multirow{2}{*}{$\begin{array}{l}\text { No./100 cm } \\
\text { leader length }\end{array}$} & \multirow{2}{*}{\multicolumn{2}{|c|}{$\begin{array}{l}\text { Mean length Crotch angle } \\
(\mathrm{cm})\end{array}$}} & & & & & & \\
\hline & & & & 1 & 2 & 3 & 4 & 5 & 6 \\
\hline Control (untreated) & $4.6 \mathrm{bc}$ & $111 \mathrm{a}$ & $64 \mathrm{a}$ & $100 \mathrm{a}$ & $0 \mathrm{~b}$ & $0 \mathrm{~b}$ & $0 \mathrm{~b}$ & $0 \mathrm{~b}$ & $0 \mathrm{~b}$ \\
\hline Bud removal & $8.5 \mathrm{a}$ & $93 \mathrm{a}$ & $61 \mathrm{a}$ & $37 \mathrm{c}$ & $25 \mathrm{a}$ & $20 \mathrm{a}$ & $10 \mathrm{a}$ & $5 \mathrm{~b}$ & $2 b$ \\
\hline Notching cuts & $4.0 \mathrm{c}$ & $123 \mathrm{a}$ & $61 \mathrm{a}$ & $74 \mathrm{~b}$ & $13 \mathrm{ab}$ & $6 \mathrm{~b}$ & $7 \mathrm{a}$ & $0 \mathrm{~b}$ & $0 \mathrm{~b}$ \\
\hline Scoring cuts & $7.1 \mathrm{ab}$ & $109 \mathrm{a}$ & $59 \mathrm{a}$ & $28 \mathrm{c}$ & $6 \mathrm{~b}$ & $9 \mathrm{ab}$ & $10 \mathrm{a}$ & $29 \mathrm{a}$ & $18 \mathrm{a}$ \\
\hline
\end{tabular}

zTreatments by hand to 1-year-old vertical, unpruned central leader shoots at green-tip (21 Mar. 2003).

${ }^{\mathrm{y}}$ Mean separation in columns by Waller-Duncan Bayesian k-ratio test following significant $\mathrm{F}$ test $(P \leq 0.05)$.

${ }^{x}$ Mean leader shoot length was $170 \mathrm{~cm}$. Leader shoot sections $30 \mathrm{~cm}$ in length; $1=$ terminal $30-\mathrm{cm}$ section.

Section 6 (basal) may have been less than or greater than $30 \mathrm{~cm}$.

Table 3. Effects of bud removal, notching, scoring, painting Promalin (PR) on buds or in rings or scoring plus PR on lateral shoot number, mean length, crotch angle, and vertical distribution in second-leaf 'Skeena'/Mazzard sweet cherry trees (Expt. 3, 2003, Bray's Landing, Wash.).

\begin{tabular}{|c|c|c|c|c|c|c|c|c|}
\hline \multirow[b]{3}{*}{ Treatment $\left(\mathrm{mg} \cdot \mathrm{L}^{-1}\right)^{\mathrm{z}, \mathrm{y}}$} & \multicolumn{3}{|c|}{ Lateral shoots } & \multirow{2}{*}{\multicolumn{5}{|c|}{$\begin{array}{l}\text { Lateral shoots in leader shoot section } \\
(\% \text { of total lateral shoots })^{\mathrm{x}}\end{array}$}} \\
\hline & \multirow{2}{*}{$\begin{array}{l}\text { No. } / 100 \mathrm{~cm} \\
\text { leader length }\end{array}$} & \multirow{2}{*}{$\begin{array}{c}\text { Mean } \\
\text { length }(\mathrm{cm})\end{array}$} & \multirow{2}{*}{$\begin{array}{c}\text { Crotch } \\
\text { angle }\left({ }^{\circ}\right)\end{array}$} & & & & & \\
\hline & & & & 1 & 2 & 3 & 4 & 5 \\
\hline Control (untreated) & $3.7 \mathrm{c}$ & $122 \mathrm{a}$ & $53 \mathrm{ab}$ & $100 \mathrm{a}$ & $0 \mathrm{~b}$ & $0 \mathrm{~b}$ & $0 \mathrm{~b}$ & $0 \mathrm{a}$ \\
\hline Paint PR (5000) on buds & $3.0 \mathrm{c}$ & $120 \mathrm{a}$ & $42 \mathrm{~b}$ & $93 \mathrm{a}$ & $7 \mathrm{bc}$ & $0 \mathrm{~b}$ & $0 \mathrm{~b}$ & $0 \mathrm{a}$ \\
\hline Paint PR (5000) rings & $2.4 \mathrm{c}$ & $126 \mathrm{a}$ & $44 \mathrm{~b}$ & $100 \mathrm{a}$ & $0 \mathrm{c}$ & $0 \mathrm{~b}$ & $0 \mathrm{~b}$ & $0 \mathrm{a}$ \\
\hline Bud removal & $7.7 \mathrm{~b}$ & $78 \mathrm{~cd}$ & $55 \mathrm{ab}$ & $45 \mathrm{c}$ & $30 \mathrm{a}$ & $15 \mathrm{a}$ & $5 \mathrm{ab}$ & $5 \mathrm{a}$ \\
\hline Notching cuts & $4.3 \mathrm{c}$ & $107 \mathrm{ab}$ & $42 \mathrm{~b}$ & $97 \mathrm{a}$ & $3 \mathrm{bc}$ & $0 \mathrm{~b}$ & $0 \mathrm{~b}$ & $0 \mathrm{a}$ \\
\hline Scoring cuts & $2.9 \mathrm{c}$ & $92 \mathrm{bc}$ & $46 \mathrm{~b}$ & $74 \mathrm{~b}$ & $13 \mathrm{bc}$ & $3 \mathrm{~b}$ & $11 \mathrm{a}$ & $0 \mathrm{a}$ \\
\hline $\begin{array}{l}\text { Scoring + paint PR } \\
(5000) \text { on cut }\end{array}$ & $15.9 \mathrm{a}$ & $57 \mathrm{~d}$ & $67 \mathrm{a}$ & $49 \mathrm{c}$ & $19 \mathrm{ab}$ & $11 \mathrm{a}$ & $13 \mathrm{a}$ & $6 \mathrm{a}$ \\
\hline
\end{tabular}

zTreatments by hand to 1-year-old vertical, unpruned central leader shoots at green-tip (24 Mar. 2003).

${ }^{\mathrm{y}}$ Mean separation in columns by Waller-Duncan Bayesian k-ratio test following significant $\mathrm{F}$ test $(P \leq 0.05)$.

${ }^{x}$ Mean leader shoot length was $129 \mathrm{~cm}$. Leader shoot sections $30 \mathrm{~cm}$ in length; $1=$ terminal $30-\mathrm{cm}$ section.

Section 5 (basal) may have been less than or greater than $30 \mathrm{~cm}$.

Table 4. Effects of bud removal, notching, scoring, painting Promalin (PR) on buds or in rings, or scoring plus PR on lateral shoot number, mean length, crotch angle, and vertical distribution in second-leaf 'Bing'/Mazzard sweet cherry trees (Expt. 4, 2003, Chelan Falls, Wash.).

\begin{tabular}{|c|c|c|c|c|c|c|c|c|}
\hline \multirow[b]{3}{*}{ Treatment $\left(\mathrm{mg} \cdot \mathrm{L}^{-1}\right)^{\mathrm{z}, \mathrm{y}}$} & \multicolumn{3}{|c|}{ Lateral shoots } & \multirow{2}{*}{\multicolumn{5}{|c|}{$\begin{array}{l}\text { Lateral shoots in leader shoot section } \\
(\% \text { of total lateral shoots })^{\mathrm{x}}\end{array}$}} \\
\hline & \multirow{2}{*}{$\begin{array}{l}\text { No./100 cm } \\
\text { leader length }\end{array}$} & \multirow{2}{*}{$\begin{array}{c}\text { Mean } \\
\text { length }(\mathrm{cm})\end{array}$} & \multirow{2}{*}{$\begin{array}{c}\text { Crotch } \\
\text { angle }\left(^{\circ}\right)\end{array}$} & & & & & \\
\hline & & & & 1 & 2 & 3 & 4 & 5 \\
\hline Control (untreated) & $4.5 \mathrm{~b}$ & $123 \mathrm{a}$ & $66 \mathrm{a}$ & $100 \mathrm{a}$ & $0 \mathrm{~d}$ & $0 \mathrm{~b}$ & $0 \mathrm{~b}$ & $0 \mathrm{~b}$ \\
\hline Paint PR (5000) on buds & $6.3 \mathrm{~b}$ & $120 \mathrm{a}$ & $69 \mathrm{a}$ & $100 \mathrm{a}$ & $0 \mathrm{~d}$ & $0 \mathrm{~b}$ & $0 \mathrm{~b}$ & $0 \mathrm{~b}$ \\
\hline Paint PR (5000) rings & $6.5 \mathrm{~b}$ & $99 \mathrm{a}$ & $69 \mathrm{a}$ & $100 \mathrm{a}$ & $0 \mathrm{~d}$ & $0 \mathrm{~b}$ & $0 \mathrm{~b}$ & $0 \mathrm{~b}$ \\
\hline Bud removal & $7.6 \mathrm{~b}$ & $98 \mathrm{a}$ & $68 \mathrm{a}$ & $43 \mathrm{~b}$ & $39 \mathrm{ab}$ & $16 \mathrm{a}$ & $2 \mathrm{~b}$ & $0 \mathrm{~b}$ \\
\hline Notching cuts & $6.3 \mathrm{~b}$ & $113 \mathrm{a}$ & $73 \mathrm{a}$ & $45 \mathrm{~b}$ & $42 \mathrm{a}$ & $12 \mathrm{ab}$ & $0 \mathrm{~b}$ & $0 \mathrm{~b}$ \\
\hline Scoring cuts & $6.2 \mathrm{~b}$ & $100 \mathrm{a}$ & $72 \mathrm{a}$ & $51 \mathrm{~b}$ & $15 \mathrm{c}$ & $10 \mathrm{ab}$ & $22 \mathrm{a}$ & $3 \mathrm{~b}$ \\
\hline Scoring + paint $\mathrm{PR}(500$ & & & & & & & & \\
\hline on cut & $19.2 \mathrm{a}$ & $63 \mathrm{~b}$ & $72 \mathrm{a}$ & $28 \mathrm{c}$ & $26 \mathrm{~b}$ & $22 \mathrm{a}$ & $15 \mathrm{a}$ & $9 \mathrm{a}$ \\
\hline
\end{tabular}

${ }^{z}$ Treatments by hand to 1-year-old vertical, unpruned central leader shoots at green-tip (24 Mar. 2003).

${ }^{y}$ Mean separation in columns by Waller-Duncan Bayesian k-ratio test following significant $\mathrm{F}$ test $(P \leq 0.05)$.

${ }^{\mathrm{x}}$ Mean leader shoot length was $121 \mathrm{~cm}$. Leader shoot sections $30 \mathrm{~cm}$ in length; $1=$ terminal $30-\mathrm{cm}$ section.

Section 5 (basal) may have been less than or greater than $30 \mathrm{~cm}$.

2004) to three vertical, unpruned 1-year-old leader shoots on each of three sets of five replicate third-leaf 'Bing'/Mazzard sweet cherry trees. One set each of the scoring treatment was then painted with $\mathrm{PR}$ at either $5000 \mathrm{mg} \cdot \mathrm{L}^{-1}$ in latex paint or $10,000 \mathrm{mg} \cdot \mathrm{L}^{-1}$ in latex paint; the third set was not painted. Control trees were untreated (four treatments 
in total). Shoot growth measurements were carried out as described for Expt. 1 and plot means were determined for statistical analysis.

Expt. 7, 2005, Malott, Washington. The following treatments were applied at greentip (14 Mar. 2005) to a single, vertical, unpruned 1-year-old leader shoot in singletree plots of second-leaf 'Skeena'/Mazzard sweet cherry trees: 1) lightly sand a ring of epidermis between two adjacent buds, starting $30 \mathrm{~cm}$ below the terminal bud and repeated at $30-\mathrm{cm}$ intervals to the base of the 1-year-old wood, with 220-grit sandpaper, avoiding physically breaking the layer, followed by painting the sanded area with $50 \% \mathrm{v} / \mathrm{v}$ latex paint; 2 ) sand as described plus paint sanded area with PER $5000 \mathrm{mg} \cdot \mathrm{L}^{-1}$ in latex paint (Fig. 1B); 3) scrape an area of epidermis between two adjacent buds, starting $30 \mathrm{~cm}$ below the terminal bud and repeated at $30-\mathrm{cm}$ intervals to the base of the 1-year-old shoot to break the brown epidermal layer visibly but disturb underlying tissues minimally, followed by painting the scraped area with $50 \% \mathrm{v} / \mathrm{v}$ latex paint; 4) scrape as described plus paint scraped area with PER $5000 \mathrm{mg} \cdot \mathrm{L}^{-1}$ in latex paint (Fig. 1D); 5) make nicking cuts about every $10 \mathrm{~cm}$ down the 1-year-old shoot with a small knife, making sure the cuts penetrate into the phloem and also distributing the cuts around the axis of the 1-year-old shoot but without regard to locating nicking cuts above buds, followed by painting each nicking cut with $50 \% \mathrm{v} / \mathrm{v}$ latex paint; 6) nick as described plus paint each nicking cut with PER $5000 \mathrm{mg} \cdot \mathrm{L}^{-1}$ in latex paint (Fig. 1F)]. Control trees were untreated (seven treatments in total). When growth was completed, the length of the treated leader shoot on each tree was measured and lateral shoots originating from the distalmost $10 \mathrm{~cm}$ of the treated leader shoot and from the remainder of the length of that shoot were counted separately.

One-way analyses of variance were used to assess the significance of treatments. All percentage values were transformed using the arcsine transformation before analysis. Mean values were separated with the WallerDuncan Bayesian k-ratio test $(P \leq 0.05)$ after a significant $F$ test. Statistical analyses were performed using the general linear models procedure of the Statistical Analysis System program package (SAS Institute, Cary, N.C.).

\section{Results}

Expts. 1 and 2. Bud removal, notching, and scoring treatments had no effect on total number of lateral shoots per $100 \mathrm{~cm} \mathrm{limb}$ length developed in 'Bing' trees (Table 1), but bud removal increased the total number of lateral shoots per $100 \mathrm{~cm}$ in 'Rainier' trees (Table 2). Mean lateral shoot lengths were unaffected by treatment in either cultivar. The typically strong controlling effect of apical dominance over lateral shoot distribution in sweet cherry was clearly demonstrated by untreated trees of both cultivars; all lateral shoot growth in controls was limited to the uppermost $30-\mathrm{cm}$ section of the 1-year-old leader shoot. Bud removal and scoring were most effective for inducing lateral shoot development from lower portions of the treated shoots. Notching produced a smaller influence on shoot development in lower portions of the treated shoots.

Expts. 3 and 4. Notching alone, scoring alone, painting PR directly on individual buds and painting rings of $P R$ on the stem between two adjacent buds had no effect on lateral shoot development or crotch angles in either cultivar, and only a very minor effect on mean lateral shoot length in 'Skeena' (Tables 3 and 4). Bud removal increased lateral shoot development in 'Skeena' only. Scoring followed by application of PR to the scoring cut was very effective in inducing an approximate fourfold increase in lateral shoot development in both cultivars, accompanied by a decrease in overall mean lateral shoot length (Fig. 2). Painting PR on buds or intact bark had no effect on lateral shoot distribution. Bud removal and notching improved the vertical distribution of lateral shoots in 'Bing', but only bud removal affected vertical shoot distribution in 'Skeena'. Scoring plus PR had the strongest effect on improving vertical lateral shoot distribution in 'Bing' and an equivalent effect to bud removal in 'Skeena'.

Expt. 5. Bud removal, notching, or scoring alone did not improve lateral shoot development in 'Rainier' trees, although some improvement in lateral shoot distribution was observed (Table 5). Painting PR on scoring or notching cuts greatly improved the lateral shoot development response and also increased the proportion of lateral shoots in the basal third of the treated leader. PR concentration did not appear to have a significant effect on lateral shoot development or vertical distribution.
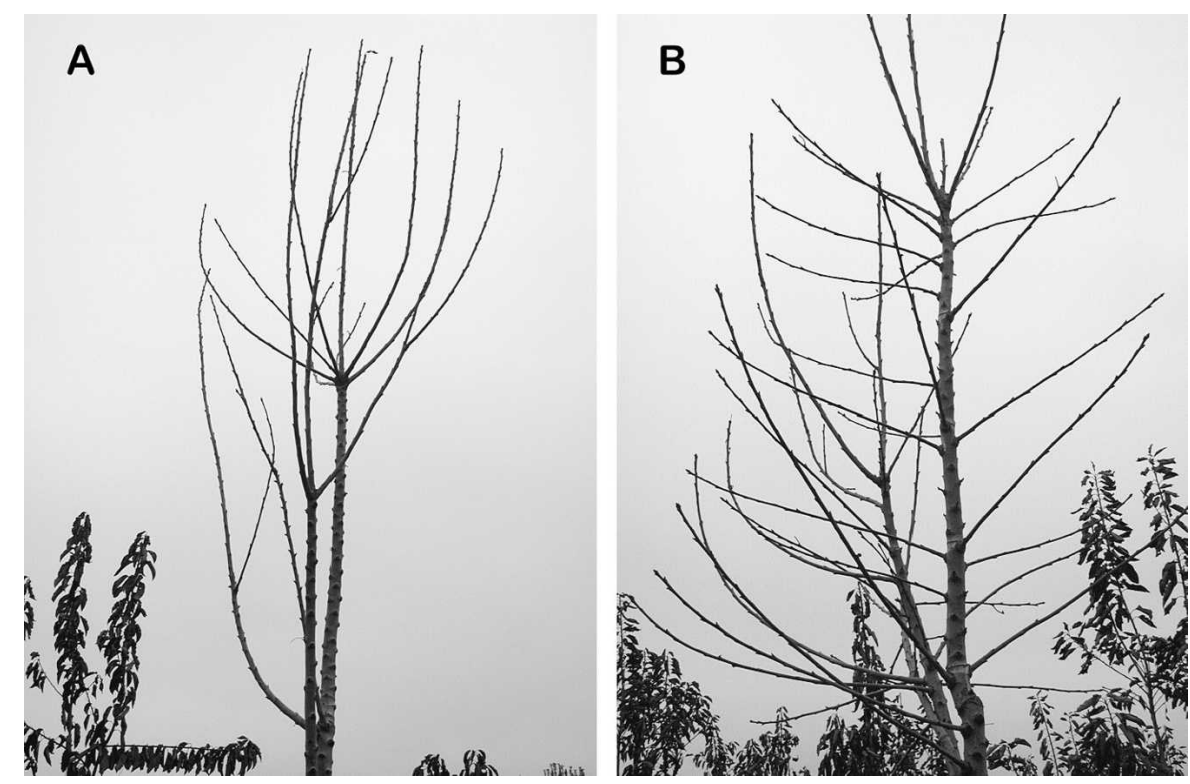

Fig. 2. Expt. 3, 2003. (A) Lateral shoot growth from unpruned leader shoot of second-leaf 'Skeena'/ Mazzard sweet cherry tree. Note the strong apical dominance effect on lateral shoot location and development. (B) Lateral shoot growth from unpruned leader shoot of similar tree receiving combination treatment of scoring every $30 \mathrm{~cm}$ plus painting PR $5000 \mathrm{mg} \cdot \mathrm{L}^{-1}$ ) on scoring cuts at green-tip. Note more shoots, shorter mean lengths, and much better vertical shoot distribution. 
Table 5. Effects of bud removal alone or notching or scoring with or without Promalin (PR) treatment on lateral shoot number and vertical distribution in third-leaf 'Rainier'/Mazzard sweet cherry trees (Expt. 5, 2004, Bray’s Landing, Wash.).

\begin{tabular}{|c|c|c|c|c|}
\hline \multirow[b]{2}{*}{ Treatment $\left(\mathrm{mg} \cdot \mathrm{L}^{-1}\right)^{\mathrm{z}, \mathrm{y}}$} & \multirow{2}{*}{$\begin{array}{c}\text { No. lateral } \\
\text { shoots } / 100 \mathrm{~cm} \\
\text { branch length }\end{array}$} & \multicolumn{3}{|c|}{$\begin{array}{l}\text { Lateral shoots in leader shoot section } \\
(\% \text { of total lateral shoots })^{\mathrm{x}}\end{array}$} \\
\hline & & 1 & 2 & 3 \\
\hline Control (untreated) & $1.5 \mathrm{e}$ & $100 \mathrm{a}$ & $0 \mathrm{~b}$ & $0 \mathrm{c}$ \\
\hline Bud removal & $3.9 \mathrm{e}$ & $95 \mathrm{ab}$ & $5 \mathrm{~cd}$ & $0 \mathrm{c}$ \\
\hline Scoring cuts & $3.4 \mathrm{e}$ & $29 \mathrm{~d}$ & $30 \mathrm{abc}$ & $40 \mathrm{a}$ \\
\hline Scoring + paint $\mathrm{PR}(50$ & & & & \\
\hline on cut & $11.9 \mathrm{~cd}$ & $49 \mathrm{~cd}$ & $30 \mathrm{abc}$ & $21 \mathrm{~b}$ \\
\hline Scoring + paint PR & & & & \\
\hline$(10,000)$ on cut & $18.7 \mathrm{bc}$ & $54 \mathrm{~cd}$ & $28 \mathrm{abc}$ & $19 \mathrm{~b}$ \\
\hline Notching cuts & $4.9 \mathrm{de}$ & $73 \mathrm{bc}$ & $15 \mathrm{bcd}$ & $12 \mathrm{~b}$ \\
\hline $\begin{array}{l}\text { Notching + paint PR } \\
(5000) \text { on notch }\end{array}$ & $24.5 \mathrm{ab}$ & $40 \mathrm{~d}$ & $43 \mathrm{a}$ & $17 \mathrm{~b}$ \\
\hline $\begin{array}{r}\text { Notching }+ \text { paint PR } \\
(10,000) \text { on notch } \\
\end{array}$ & $27.4 \mathrm{a}$ & $46 \mathrm{~d}$ & $39 \mathrm{ab}$ & $15 \mathrm{~b}$ \\
\hline
\end{tabular}

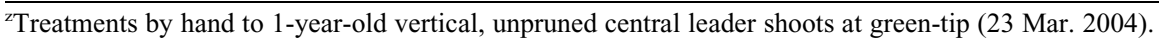

${ }^{\mathrm{y}}$ Mean separation in columns by Waller-Duncan Bayesian k-ratio test following significant $\mathrm{F}$ test $(P \leq 0.05)$.

${ }^{x}$ Mean leader shoot length was $156 \mathrm{~cm}$. Leader shoot sections roughly one-third the total length of the leader shoot; 1 = terminal, 3 = basal.

Table 6. Effects of scoring cuts or scoring plus Promalin (PR) application to the scoring cuts on lateral shoot number, mean length, crotch angle, and vertical distribution in third-leaf 'Bing'/Mazzard sweet cherry trees (Expt. 6, 2004, Chelan Falls, Wash.).

\begin{tabular}{|c|c|c|c|c|c|c|c|c|c|}
\hline \multirow[b]{3}{*}{ Treatment $\left(\mathrm{mg} \cdot \mathrm{L}^{-1}\right)^{\mathrm{z}, \mathrm{y}}$} & \multicolumn{3}{|c|}{ Lateral shoots } & & & & & & \\
\hline & \multirow{2}{*}{$\begin{array}{l}\text { No. } / 100 \mathrm{~cm} \\
\text { leader length }\end{array}$} & \multirow{2}{*}{$\begin{array}{l}\text { Mean } \\
\text { length } \\
(\mathrm{cm})\end{array}$} & \multirow{2}{*}{$\begin{array}{c}\text { Crotch } \\
\text { angle } \\
\left({ }^{\circ}\right)\end{array}$} & \multicolumn{6}{|c|}{$\begin{array}{l}\text { Lateral shoots in leader shoot section } \\
(\% \text { of total lateral shoots })^{\mathrm{x}}\end{array}$} \\
\hline & & & & 1 & 2 & 3 & 4 & 5 & 6 \\
\hline Control (untreated) & $2.2 \mathrm{~d}$ & $83 \mathrm{a}$ & $54 \mathrm{a}$ & $93 \mathrm{a}$ & $0 \mathrm{~b}$ & $0 \mathrm{~b}$ & $0 \mathrm{~b}$ & $7 \mathrm{~b}$ & 0 \\
\hline Scoring cuts & $9.8 \mathrm{c}$ & $64 \mathrm{a}$ & $58 \mathrm{a}$ & $8 \mathrm{~b}$ & $13 \mathrm{a}$ & $14 \mathrm{~b}$ & $25 \mathrm{a}$ & $27 \mathrm{a}$ & 12 \\
\hline $\begin{array}{l}\text { Scoring }+ \text { paint PR } \\
(5000) \text { on cuts }\end{array}$ & $17.8 \mathrm{~b}$ & $39 \mathrm{~b}$ & 59 a & $20 \mathrm{~b}$ & $18 \mathrm{a}$ & $18 \mathrm{ab}$ & $21 \mathrm{a}$ & $17 \mathrm{a}$ & \\
\hline $\begin{array}{l}\text { Scoring }+ \text { paint PR } \\
(10,000) \text { on cuts }\end{array}$ & $21.6 \mathrm{a}$ & $34 \mathrm{~b}$ & $55 \mathrm{a}$ & $15 \mathrm{~b}$ & $17 \mathrm{a}$ & $26 \mathrm{a}$ & $24 \mathrm{a}$ & $14 \mathrm{ab}$ & 4 \\
\hline
\end{tabular}

${ }^{z}$ Treatments by hand to 1-year-old vertical, unpruned central leader shoots at green-tip (24 Mar. 2003).

${ }^{\mathrm{y}}$ Mean separation in columns by Waller-Duncan Bayesian k-ratio test following significant $\mathrm{F}$ test $(P \leq 0.05)$.

${ }^{\mathrm{x}}$ Mean leader shoot length was $187 \mathrm{~cm}$. Leader shoot sections $30 \mathrm{~cm}$ in length; $1=$ terminal 30-cm section.

Section 6 (basal) may have been less than or greater than $30 \mathrm{~cm}$.

Table 7. Effects of breaking the epidermal layer alone or breaking that layer plus Perlan (PER) application to the sanded, scraped, or nicked areas on lateral shoot number originating from the terminal $10 \mathrm{~cm}$ of the treated branch and from the remainder of the branch in second-leaf 'Skeena'/Mazzard sweet cherry trees (Expt. 7, 2005, Malott, Wash.).

\begin{tabular}{|c|c|c|}
\hline Treatment $\left(\mathrm{mg} \cdot \mathrm{L}^{-1}\right)^{\mathrm{z}, \mathrm{y}}$ & $\begin{array}{l}\text { Lateral shoots originating } \\
\text { from terminal } 10 \mathrm{~cm} \text { of } \\
\text { 1-year-old leader branch (n) }\end{array}$ & $\begin{array}{c}\text { Lateral shoots on } \\
\text { remainder of } 1 \text {-year-old leader } \\
\text { branch (no./100 cm of branch) }\end{array}$ \\
\hline Control (untreated) & $6.2 \mathrm{a}$ & $0.1 \mathrm{~b}$ \\
\hline Lightly sand epidermis + paint only & $6.4 \mathrm{a}$ & $0.0 \mathrm{~b}$ \\
\hline Sand + paint PER (5000) on sanded area & $7.2 \mathrm{a}$ & $1.4 \mathrm{~b}$ \\
\hline Scrape epidermis + paint only & $7.4 \mathrm{a}$ & $1.8 \mathrm{~b}$ \\
\hline \multicolumn{3}{|l|}{ Scrape epidermis + paint PER $(5000)$} \\
\hline on scraped area & $7.6 \mathrm{a}$ & $10.6 \mathrm{a}$ \\
\hline Nicking cuts + paint only & $8.0 \mathrm{a}$ & $0.1 \mathrm{~b}$ \\
\hline \multicolumn{3}{|l|}{ Nicking + paint PER $(5000)$ on } \\
\hline nicking cuts & $7.8 \mathrm{a}$ & $10.0 \mathrm{a}$ \\
\hline
\end{tabular}

1-year-old shoots was completely ineffective for induction of lateral shoot development, even though the treated buds had some green tissue exposed at the time of treatment. Results from other studies indicate that cytokinin-GA products are effective for inducing sweet cherry buds to grow into shoots (Elfving and Visser, 2006; Jacyna and Puchała, 2004; Miller, 1983; Veinbrants and Miller, 1981). Results of the trials reported here tissues are minimally disturbed, substantial lateral shoot growth is promoted and new shoots are produced from buds located on the lower portions of 1-year-old shoots, improving shoot distribution. Entire shoots or branches do not require complete coverage with cytokinin-containing bioregulators as described by Jacyna and Puchała (2004), Miller (1983) and Veinbrants and Miller (1981). When combined with nicking, notching, scoring, or scraping, spot treatment with cytokinin-GA mixtures at intervals down a 1 -year-old shoot is sufficient to produce substantial new and well-distributed shoot development. The shoot development response to these treatments is somewhat localized. Cuts plus bioregulators need to be applied at intervals on 1-year-old shoots to ensure good distribution of the induced lateral shoots along the treated 1-year-old shoots.

When bioregulator treatments were effective at overcoming apical dominance, new shoot growth was increased severalfold in some trials reported here. Although some of these shoots might subsequently be removed, this large increase in lateral shoots and the consequent increase in lateral buds should result in greater productivity when the trees begin to flower. Combining whole-tree treatments for improved lateral shoot development with reduced pruning and the use of precocious, size-controlling rootstocks should further improve early productivity. Further tests are necessary to verify this hypothesis.

When sweet cherry bark is injured, infection by the bacterial canker pathogen $[\mathrm{Pseu}$ domonas syringae pv. syringae van Hall or P. s. pv. morsprunorum (Wormald) Young et al.] may occur (Ogawa et al., 1995). However, during 4 years of branching trials involving scoring and notching cuts made on several cultivars in numerous locations under both dry and wet conditions in the early spring around green-tip, we have never observed an infection by this pathogen under central Washington state conditions. Combining cytokinin-GA treatments with bark scraping, nicking, notching, or scoring may offer a less labor-intensive, practical alternative to heavy pruning or painting entire shoots or limbs with bioregulator products for stimulation of lateral shoot and canopy development, especially in higher density sweet cherry plantings.

\section{Literature Cited}

Cody, C.A., F.E. Larsen, and R. Fritts, Jr. 1985a. Induction of lateral branches in tree fruit nursery stock with propyl-3-t-butylphenoxy acetate $(M \& B \quad 25,105)$ and Promalin $\left(\mathrm{GA}_{4+7}\right.$ +6-benzyladenine). Sci. Hort. 26:111-118.

Cody, C.A., F.E. Larsen, and R. Fritts, Jr. 1985b. Stimulation of lateral branch development in tree fruit nursery stock with $\mathrm{GA}_{4+7}+\mathrm{BA}$ HortScience 20:758-759.

Cook, N.C. and D.K. Strydom. 2000. The South African high density system. Acta Hort. 513:321-327.

Elfving, D.C. 1990. Growth and productivity of 'Empire' apple trees following a single heading-back pruning treatment. HortScience 25:908-910. 
Elfving, D.C. and D.B. Visser. 2005. Cyclanilide induces lateral branching in apple trees. HortScience 40:119-122.

Elfving, D.C. and D.B. Visser. 2006. Cyclanilide induces lateral branching in sweet cherry trees. HortScience 41:149-153.

Greene, D.W. and W.P. Autio. 1994. Notching techniques increase branching of young apple trees. J. Amer. Soc. Hort. Sci. 119:678-682.

Greene, D.W. and P. Miller. 1988. Effects of growth regulator sprays and notching on growth and branching of 'Starkrimson Delicious' apple trees. J. Amer. Soc. Hort. Sci. 113:18-23.

Hrotkó, K., L. Magyar, and B. Öri. 1999. Improved feathering on one-year-old 'Germersdorfi FL 45 ' sweet cherry trees in the nursery. Gartenbauwiss. 64:75-78.

Jacyna, T. 2002. Factors influencing lateral-branch formation in woody plants. Acta Agrobot. 55:2-25.

Jacyna, T., J. Barnard, and R.L. Andersen. 2005. Natural growth habit of sweet cherry maiden trees. J. Amer. Pom. Soc. 59:104-110.

Jacyna, T. and G. Brown. 1989a. Earnscleugh canopy: How to create it. Orchardist N.Z. 62:16-17.

Jacyna, T. and G. Brown. 1989b. Earnscleugh canopy: The answer for cherries. Orchardist N.Z. $62: 13,15$.

Jacyna, T. and A. Puchała. 2004. Application of environment friendly branch promoting substances to advance sweet cherry tree canopy development in the orchard. J. Fruit Ornament. Plant Res. 12:177-182.

Jacyna, T., D.E.S. Wood, and S.M. Trappitt. 1989. Application of paclobutrazol and Promalin
$\left(\mathrm{GA}_{4+7}+\mathrm{BAP}\right)$ in the training of 'Bing' sweet cherry trees. N. Z. J. Crop Hort. Sci. 17:41-47.

Long, L. 2001. Cherry training systems: Selection and development. Pacific Northwest Extension publication PNW 543. Oregon State Univ., Corevalis, Ore.

Long, L. 2005. Sweet cherry training systems: Current practices in North America and Europe. Compact Fruit Tree 38:20-23.

Long, L.E., T. Facteau, R. Nuñez-Elisea, and H. Cahn. 2005. Developments in high density cherries in the USA. Acta Hort. 667: 303-309.

Mika, A., M.J. Grochowska, A. Karaszewska, and M.W. Williams. 1983. Effects of dormant and summer pruning, bud removal, and growth retardants on growth, flower bud formation, and fruiting of young apple trees. J. Amer. Soc. Hort. Sci. 180:655-660.

Miller, P. 1983. The use of Promalin for manipulation of growth and cropping of young sweet cherry trees. J. Hort. Sci. 58:497-503.

Neri, D., M. Mazzoni, F. Zucconi, and G. Dradi. 2003. Il controllo della formazione dei rami anticipati nel ciliegio dolce. Riv. Frutt. Ortofloricoltura 65:47-53.

Niu, Z.M., M.K. Chen, J.B. Sun, J. Lu, and Y.M. Xu. 1998. Effects of bud notching on the endogenous hormone contents and shoot sprouting of apple trees. J. Fruit Sci. 15:198-202.

Nugent, J., G. Lang, W. Shane, and R. Perry. 2001. Dwarf rootstocks for sweet cherries have benefits. Fruit Growers News 40:28, 30, 31.

Ogawa, J.M., E.I. Zehr, G.W. Bird, D.F. Ritchie, K. Uriu, and J.K. Uyemoto. 1995. Compen- dium of stone fruit diseases. APS Press, St. Paul, Minn.

Ouellette, D.R., C.R. Unrath, and E. Young. 1996. Manual and chemical branch inducement in fall- and spring-planted 'Empire' apple on two rootstocks. HortScience 31:82-88.

Peano, C., G. Giacalone, V. Chiabarndo, and T. la Iacona. 2005. Potatura lunga e diradamento delle gemme nel controllo vegeto-produttivo del melo. Riv. Frutt. Ortofloricoltura 67: 38-41.

Perry, R. 1999. Debudding: Clothespins critical to developing dwarf sweet cherries. Fruit Growers News 38:34-35.

Robinson, T., S. Hoying, and R. Andersen. 2005. Management of high-density sweet-cherry orchards. N.Y. Fruit Q. 13:24-27.

Sachs, T. and K.V. Thimann. 1967. The role of auxins and cytokinins in the release of buds from dominance. Nature 201:939-940.

Theron, K.I., G. Jacobs, and D.K. Strydom. 1987. Correlative inhibition of axillary buds in apple nursery trees in relation to node position, defoliation, and Promalin application. J. Amer. Soc. Hort. Sci. 112:732-734.

Veinbrants, N. and P. Miller. 1981. Promalin promotes lateral shoot development of young cherry trees. Aust. J. Exp. Agr. Anim. Husb. 21:618-622.

Wickson, M. and K.V. Thimann. 1958. The antagonism of auxin and kinetin in apical dominance. Physiol. Plant. 11:62-74.

Wustenberghs, H. and J. Keulemans. 1999. Le cerisier a fruits doux: Amelioration de la qualite des plants. Le Fruit Belge 67:106110. 